\title{
ANALISIS LANDASAN ILMU PENGETAHUAN DAN TEKNOLOGI DALAM PENGEMBANGAN KURIKULUM
}

\author{
Farrah Camelia \\ Pendidikan Agama Islam, UIN Sunan Kalijaga, Yogyakarta \\ Email: : 19204010003@student.uin-suka.ac.id
}

\begin{abstract}
Abstrak
Kemajuan suatu negara didukung oleh kualitas sumber daya manusia di dalamnya, kemajuan teknologi dan pengetahuan merupakan dua hal yang sangat berpengaruh terhadap perkembangan negara tersebut. Tantangan masa depan berupa perkembangan teknologi informasi, konvergensi ilmu dan teknologi, kemajuan industri kreatif dan budaya, pengaruh serta dampak teknosains, menuntut pelaksanaan pengembangan kurikulum dengan landasan ilmu pengetahuan dan teknologi yang lebih komprehensif. Kajian ini bertujuan untuk menambah wawasan pembaca mengenai pentingnya peningkatan mutu sumber daya manusia dengan memperbaiki pendidikan di Indonesia, salah satunya melalui pengembangan kurikulum yang berlandaskan ilmu pengetahuan dan teknologi. Metode penelitian dengan menggunakan pendekatan kualitatif deskriptif. Hasil kajian menjelaskan bahwa lembaga pendidikan khususnya jalur sekolah harus mampu menunjang dan mengantisipasi kemajuan ilmu pengetahuan dan teknologi. Bahan ajar atau materi sepatutnya hasil perkembangan ilmu pengetahuan dan teknologi kontemporer, baik berkaitan dengan hasil perolehan informasi, ataupun cara memperoleh informasi tersebut dan memanfaatkannya untuk masyarakat. Dibutuhkan pemanfaatan, pengembangan dan penguasaan ilmu pengetahuan dan teknologi supaya memberi implikasi terhadap pengembangan sumber daya manusia.
\end{abstract}

Kata Kunci : Ilmu Pengetahuan dan Teknologi, Kurikulum

\begin{abstract}
The progress of a country is supported by the quality of human resources in it. technological progress and knowledge are two things that are very influential on the development of the country. Future challenges include the development of information technology, the convergence of science and technology, the advancement of creative and cultural industries, the influence and impact of science, demanding the implementation of curriculum development with a more comprehensive foundation of science and technology. This study aims to broaden the reader's insight on the importance of improving the quality of human resources by improving education in Indonesia, one of which is through the development of a curriculum based on science and technology. The research methods used was the qualitatif descriptive approach. The results of the study explained that, educational institutions especially the school path must be able to support and anticipating the progress of science and technology. Teaching materials or materials should be the result of the development of contemporary science and technology, both related to the results of information acquisition, or how to obtain this information and use it for the community. It takes the use, development and mastery of science and technology in order to have implications for the development of human resources.
\end{abstract}

Key Words : Science and Technology, Curriculum

\section{PENDAHULUAN}

Kemajuan suatu negara didukung oleh kualitas sumber daya manusia (SDM) di dalamnya, kemajuan teknologi dan pengetahuan merupakan dua hal yang paling memberi pengaruh terhadap perkembangan negara tersebut. Semua negara maju di dunia disebabkan karena kemampuan SDM yang ditunjang dengan kemajuan teknologi dalam mengolah sumber daya alam mereka. Kemajuan teknologi informasi bergerak dengan cepat dan pesat mengubah dunia secara modern dalam berbagai bidang.

Berdasarkan data yang disebutkan World Economic Forum (WEF) 2017 terkait Human Capital Index memperlihatkan 
peringkat Indonesia dari peringkat $65 \mathrm{di}$ tahun 2017, mengalami penurunan menjadi peringkat 87 dari total 157 negara, dengan skor 0,53 [1]. Sebagai perbandingan, terdapat 3 negara di Asia Tenggara yang memiliki peringkat di atas Indonesia; yaitu Singapura dengan skor 0,88 dan Vietnam 0,67. Apabila Indonesia tidak melakukan perbaikan, dikhawatirkan anak-anak Indonesia mengalami kesulitan untuk bersaing di tengah persaingan global. Oleh karena itu, dalam lima tahun ke depan pemerintah merencanakan untuk fokus membentuk sumber daya manusia unggul. Peningkatan kualitas pendidikan merupakan sebuah proses terintegrasi dengan proses peningkatan kualitas sumber daya manusia melalui dukungan sarana dan prasarana dan keinginan untuk meningkatkan mutu pendidikan [2].

Sistem Pendidikan Nasional Indonesia yang diatur melalui undang-undang No. 20 tahun 2003 oleh Sekretaris Negara Republik Indonesia pada tanggal 8 Juli 2003 di Jakarta. Sistem pendidikan Indonesia terus meningkatkan perubahan dengan tujuan menciptakan sistem pendidikan yang lebih bermutu, dengan kurikulum yang lebih baik untuk melahirkan lulusan yang lebih baik pula. Dalam konteks pendidikan yang mengaktualisasikan visi pembelajaran abad 21, UNESCO menawarkan empat pilar dalam bidang pendidikan, yakni: 1) Learning to know, 2) Learning to do, 3) Learning to live together, 4) Learning to be. Pendidikan yang membangun kompetensi "partnership 21st Century Learning" yaitu menuntut peserta didik agar menguasai keterampilan, pengetahuan, dan kemampuan di bidang media, teknologi dan informasi [3].

Untuk merealisasikan empat pilar tersebut, harus disusun dan dikembangkan suatu sistem kurikulum secara saksama. Kurikulum yang disusun secara saksama itu antara lain disesuaikan dengan perkembangan ilmu pengetahuan dan teknologi (IPTEK) [4]. Zakiyah Daradjat berpendapat bahwa kurikulum sebagai suatu program yang direncanakan dalam bidang pendidikan dan diimplementasikan untuk mencapai tujuan pendidikan tertentu [5]. Pengembangan kurikulum merupakan dinamika yang dapat memberi respon terhadap tuntutan transformasi perkembangan ilmu pengetahuan dan teknologi, maupun globalisasi [6].

Berdasarkan penjelasan tersebut, maka perlu membangun perubahan pada sistem dan isi pendidikan yang terwujud dalam pembaruan kurikulum. Asas perkembangan pendidikan dan pembelajaran akan selalu mengikuti perkembangan IPTEK. Pengaruh langsung dari kemajuan IPTEK di sini adalah dalam memberikan materi atau bahan yang disampaikan dalam pendidikan. Oleh karena itu, kajian ini berfokus pada landasan IPTEK dalam pengembangan kurikulum. Tujuan penelitian agar kurikulum sebagai pusat muatan nilai tidak mengalami disparitas kualitas pendidikan, sehingga tidak melahirkan output pendidikan yang 'kelabakan' dalam beradaptasi dengan konteks sosial.

\section{METODE}

Penelitian ini menggunakan pendekatan kualitatif deskriptif. Bahan kajian yang menjadi rujukan yaitu 6 jurnal, 9 buku, 2 tesis, dan beberapa data lain yang berkaitan dengan topik tulisan terutama mengenai IPTEK serta kurikulum.

\section{HASIL DAN PEMBAHASAN Ilmu Pengetahuan dan Teknologi}

Ilmu dalam bahasa Indonesia seringkali dipadankan dengan sains (science), dan disandingkan dengan kata pengetahuan, menjadi ilmu pengetahuan. Ilmu ialah pemahaman atau kesadaran mengenai suatu pengetahuan, dengan fungsi untuk 
mencari, menyelediki, menganalisis suatu hipotesis. Ilmu memiliki arti sebuah pengetahuan yang didapat dengan menempuh beberapa metode dalam belajar dan pengalaman. Ilmu dapat dikatakan sebuah pengetahuan yang telah valid kebenarannya.

Adapun pengetahuan merupakan suatu informasi yang disadari dan diketahui seseorang. Pengetahuan dapat diperoleh dengan cara mengalami atau mendapatkan dari orang lain. Akan tetapi pengetahuan belum bisa disebut ilmu jika kebenarannya belum teruji. Asal muasal manusia memperoleh pengetahuan dari fakta yang tidak akurat, tidak sistematis, dan tidak berdasar pada teori yang jelas. Sesuai dengan berkembangnya budaya, manusia mulai menyusun teori mengenai banyak hal sesuai fakta yang ada. Dalam perkembangannya, fakta beserta teori itu digunakan untuk memahami fenomena lain yang didukung oleh pengalaman. Menurut Hilda Taba, pengetahuan itu memiliki tingkatan berupa; a) Adanya konsep, b) Ide-ide pokok, c) Metode perumusan, dan d) Fakta realitas [7].

Beberapa syarat sesuatu bisa dikatakan sebagai ilmu, antara lain: a) Bersifat objektif, b) Metodis yaitu cara yang dilakukan untuk mencegah adanya kesalahan dalam melakukan pencarian terkait hakikat kebenarannya sesuatu, c) Sistematis yaitu sebuah rincian yang terstruktur dalam melakukan pengkajian terhadap suatu objek serta dapat menyimpulkannya menjadi lebih sederhana, d) Universal yaitu kebenaran yang didapat setelah melakukan pengkajian bersifat umum yang artinya bisa diterima oleh semua atau sebagian besar lingkungan dan realitas [8]. Pengetahuan dan pengalaman akan menjadi ilmu pengetahuan apabila pengetahuan tersebut disusun dengan objektif, metodis, sistematis, dan universal, sesuai prosedur kerja hukum kausalitas pada masalah yang dialami.

IPTEK yang dimiliki manusia pada awalnya sederhana, akan tetapi menginjak abad pertengahan mengalami perkembangan yang cukup pesat. Seiring dengan kemajuan teknologi, akal manusia juga diajak berkembang. Hal ini dibuktikan ketika dahulu kala sangat mustahil ada manusia yang dapat pergi ke bulan apalagi menginjakkan kaki di sana, namun kemajuan IPTEK di pertengahan abad 20 membuktikan pesawat Apollo 11 berhasil mendarat di bulan [9]. Perkembangan ilmu pengetahuan masa kini lahir berkat sumbangsih pemikiran dan penemuan para filsuf seperti Socrates, Plato, Aristoteles, Archimedes, Jhon Dewey dan lainnya. Perkembangan tersebut menghasilkan temuan baru di bidang sosial, budaya, ekonomi, politik dan lain sebagainya.

Teknologi hakikatnya merupakan implementasi dari ilmu pengetahuan dan menduduki peranan penting dalam kehidupan manusia. Teknologi lahir dari karya pikir manusia melalui proses ilmiah guna mencapai tujuan yang optimal, teknologi juga dapat diartikan sebagai sarana manusia untuk menyediakan kebutuhan. Tujuannya ialah menciptakan suatu kondisi yang efektif, efisien, dan sinergis terhadap pola perilaku manusia. Salah satu indikator kemajuan peradaban manusia salah satunya dapat diukur dari kemajuan IPTEK. Teknologi dibuat untuk mendukung kehidupan manusia di semua aspek. Adanya teknologi memudahkan manusia dalam mengembangkan sumber daya alam yang ada, namun sering kali melampaui batas sehingga sering terjadi ketidakseimbangan dalam penggunaannya dan kerakusan manusia yang menyebabkan terjadinya bencana alam.

IPTEK merupakan hasil dari gagasangagasan manusia dan bersifat objektif 
sehingga mudah diterima dan dijangkau oleh masyarakat. Dengan adanya IPTEK dapat memudahakan dalam menyampaikan informasi sehingga menyebabkan perubahan dan perkembangan pada budaya. Perkembangan tersebut membuat pola pikir dan hidup masyrakat terus berubah mengikuti kemajuan. Apabila masyarakat tidak dapat mengikutinya maka mereka akan ketinggalan sehingga membuat mereka kesusahan dalam memanfaatkan sumber daya alam. Berdasarkan hal itu, sebuah bangsa atau Negara akan mengalami kemunduran karena rakyat di dalamnya tidak mampu memanfaatkan sumber daya alam dalam hal IPTEK.

Di Indonesia sendiri pembangunan industri sampai saat ini belum sepenuhnya didukung oleh potensi unggul baik pendidikan, termasuk sumber daya manusianya. Hal ini ditunjukkan oleh Indeks Pendidikan, data yang digunakan untuk mengukur indeks pendidikan terbatas pada data melek huruf dan gross enrolment ratio dari Sekolah Dasar, Menengah hingga Perguruan Tinggi (SD, SM dan PT). IPTEK belum sepenuhnya dimanfaatkan oleh masyarakat Indonesia khususnya pendidik dan peneliti yang belum mengembangkan penelitian secara optimal [10]. Pengajar harus terus mengikuti perkembangan IPTEK supaya bisa menyampaikan materi pembelajaran yang mutakhir dan bermanfaat bagi kehidupan peserta didik saat ini dan masa depan. Dengan demikian, menjadi searah dengan upaya pembaruan kurikulum yang seiring dengan kemajuan IPTEK dalam hampir semua bidang kehidupan.

\section{Pengembangan Kurikulum}

Di dalam bahasa Arab, kurikulum biasa disebut dengan manhaj yang artinya jalan atau cara [11]. Sedangkan kurikulum berdasarkan UU No. 20 Tahun 2003 terkait Sistem Pendidikan Nasional, kurikulum adalah sebuah alat dengan cara atau metode yang telah disiapkan untuk menyelenggarakan tujuan yang sudah direncanakan. Kurikulum yang semulanya hanya dimaknai dengan mata pelajaran, namun sekarang beralih pemaknaan menjadi semua kegiatan yang bersangkutan dengan pembelajaran dalam upaya mencapai tujuan pendidikan [12]. Menurut Doll bahwa terkait perubahan pemaknaan tersebut ialah dimana pengertian tentang kurikulum yang semulanya berkenaan dengan mata pelajaran atau studi namun sekarang berubah menjadi semua kegiatan di dalam pembelajaran yang diupayakan oleh sekolah [13].

Beberapa tahun terakhir terjadi pola pikir terkait mendidik anak, di mana sebelumnya para orang tua mempercayakan tentang pendidikan anaknya sepenuhnya kepada guru, padahal waktu di luar sekolah lebih banyak dihabiskan oleh anak, artinya seorang lebih sering di rumah dan bersama keluarga dan yang seharusnya orang tua lah yang mendidik anaknya bukan menyerahkannya kepada guru.

Oleh karena semakin berkembangnya IPTEK membuat kurikulum sekolah harus terus mengikuti kemajuan tersebut, sehingga akhirnya kurikulum memiliki banyak tanggung jawab dan permasalahan yang harus diselesaikan untuk dapat menyesuaikan pembelajaran dengan kemajuan dari IPTEK. Beberapa penjelasan tersebut menunjukkan betapa luas pengertian kurikulum. Supaya mendapatkan pelajaran yang luas, seorang siswa harus memiliki pengalaman dalam bergaul dengan semua anggota atau orang yang terlibat di sekolah dan alat-alat yang ada.

Para ahli serta pelaksana kurikulum berbeda-beda dalam mengartikan 
"pengembangan" kurikulum. Winarno Surahmad dalam Sukiman, mengartikan kegiatan pengembangan kurikulum ialah usaha dalam mengembangkan dan menyempurnakan perencanaan yang ada di dalam kurikulum. Pengembangan kurikulum ialah istilah yang komprehensif, di dalamnya meliputi: perencanaan, pelaksanaan, dan evaluasi [14].

Dalam pengembangan kurikulum, tidak hanya menyertakan orang yang terlibat langsung dengan dunia pendidikan saja, namun di dalamnya melibatkan banyak orang, di antaranya: politikus, pengusaha, orang tua peserta didik, serta unsur-unsur masyarakat lainnya yang memiliki kepentingan dengan pendidikan. Dalam hal ini, lembaga sekolah bertanggung jawab menerapkan kerangka kerja dalam mengoptimalkan kurikulum. Di dalam kerangka kerja tersebut berisi informasi mengenai: 1) Apa yang harus dipelajari dan dipahami peserta didik (subyek), 2) Apa kompetensi peserta didik, 3) Berapa lama mereka dapat belajar (jam belajar), dan 4) Dengan cara bagaimana peserta didik belajar (tatap muka, tugas individu, tugas terstruktur). Pada hakikatnya kurikulum mengarah pada tujuan pendidikan nasional yakni mencerdaskan kehidupan bangsa. Cerdas yang ingin dicapai di sini bukan hanya pandai dan terampil tetapi mempunyai kemampuan dan kemauan untuk memanfaatkan kepandaian serta keterampilan tersebut dalam menyelesaikan berbagai persoalan dalam kehidupan bermasyarakat.

Tahapan pengembangan kurikulum dilaksanakan dengan mengembangkan keempat elemen utama kurikulum, antara lain: mengembangkan tujuan, materi, metode dan evaluasi. Setiap elemen kurikulum merupakan suatu kesatuan yang saling berhubungan dan saling memengaruhi. Sebagaimana pendapat Munir [4], dalam pengembangan kurikulum, setiap pengembangan satu komponen dapat memengaruhi pengembangan komponen yang lain.

Pengembangan kurikulum perlu juga memerhatikan prinsip-prinsip pengembangan yang menjadi rambu-rambu kaidah yang terkandung dalam kurikulum itu sendiri. Terutama pada tahap perencanaan yang menggambarkan ciri suatu kurikulum.

Menurut Sukmadinata [9], prinsip kurikulum terbagi menjadi dua yaitu:

1. Prinsip umum, antara lain:

a. Prinsip relevansi

Kesesuaian atau relevan terbagi menjadi dua jenis, relevansi internal dan eksternal. Relevansi internal yaitu menyesuaikan antar komponen kurikulum (tujuan, isi, metode, evaluasi) agar mencapai tujuan tertentu, belajar, dan kemampuan peserta didik. Kurikulum dapat dinilai baik jika terdapat koherensi dan konsistensi antar komponen dalam relevansi internal. Relevansi eksternal yaitu menyesuaikan kurikulum dengan kebutuhan masyarakat (masa kini dan masa depan). Kurikulum dituntut menyiapkan program belajar bagi peserta didik agar dapat beradabtasi dengan lingkungan masyarakat dimana ia berada. Pakar pengembang kurikulum harus memiliki wawasan tentang kehidupan masyarakat masa sekarang dan masa yang akan datang, artinya pengembang kurikulum harus dapat memprediksi masa depan agar dapat memenuhi kebutuhan relevansi eksternal.

b. Prinsip fleksibilitas

Kurikulum harus lentur, artinya sistem yang ada dalam kurikulum memberi alternatif dalam mencapai tujuan, menyesuaikan strategi dan 
metode dengan situasi dan kondisi tertentu.

c. Prinsip efektivitas

Kurikulum berorientasi kepada tujuan yang ingin dicapai. Kurikulum sebagai instrumen pencapaian tujuan, maka jenis dan karakteristik tujuan harus jelas. Kejelasan tujuan akan mengarah pada penentuan isi, metode dan sistem evaluasi juga model dan konsep kurikulum apa yang hendak digunakan. Tujuan tersebut dapat mempermudah implementasi kurikulum.

d. Prinsip efisiensi

Pengembang kurikulum harus memahami situasi dan kodisi tempat kurikulum akan dilaksanakan, tujuannya agar desain kurikulum memenuhi prinsip 'praktis' atau mudah diterapkan di lapangan.

e. Prinsip kontinuitas

Kurikulum yang disusun harus berkesinambungan baik antar kelas maupun jenjang pendidikan, dengan tujuan agar proses belajar mengajar bisa maju secara berkesinambungan. Maka dibutuhkan kerja sama antara pengembang kurikulum dari berbagai kelas dan jenjang pendidikan.

\section{Prinsip khusus}

Prinsip-prinsip khusus hanya berlaku pada tempat dan situasi tertentu. Misalnya suatu jenjang dan jenis pendidikan di masing-masing wilayah memiliki karakteristik berbeda di beberapa aspek. Prinsip tersebut menunjukkan adanya perbedaan penggunaan prinsip yang khas. Prinsipprinsip khusus, yaitu:

a. Prinsip mengenai tujuan pendidikan.

b. Prinsip mengenai isi pendidikan.

c. Prindip mengenai proses pembelajaran.

d. Prinsip mengenai alat bantu dan media pembelajaran.

e. Prinsip mengenai evaluasi.

\section{Landasan Ilmu Pengetahuan dan Teknologi dalam Pengembangan Kurikulum}

Landasan pengembangan kurikulum layaknya fondasi bangunan. Gedung menjulang tinggi akan roboh jika berdiri di atas fondasi yang rapuh, oleh karena itu sebelum membangun sebuah gedung maka perlu membangun fondasi yang kokoh terlebih dahulu. Perkembangan IPTEK juga sebagai pemacu kemajuan pembangunan. Perkembangan IPTEK secara langsung berimplikasi terhadap pengembangan kurikulum yang di dalamnya mencakup pembaruan isi atau materi pendidikan, penggunaan strategi dan media pembelajaran, serta penggunaan sistem evaluasi [15]. Materi pelajaran sepatutnya hasil perkembangan IPTEK kontemporer, baik berhubungan dengan hasil perolehan informasi, ataupun cara memperoleh informasi tersebut dan memanfaatkannya untuk masyarakat. Tentu dalam proses pengembangan kurikulum harus tetap mengacu kepada prinsip-prinsip yang telah ditetapkan.

Dukungan IPTEK kepada pembangunan dapat mewujudkan masyarakat maju, mandiri dan sejahtera. Perkembangan IPTEK semakin cepat dan persaingan antar-bangsa makin meluas. Oleh karena itu dibutuhkan pemanfaatan, pengembangan dan penguasaan IPTEK yang mana akan memberi implikasi terhadap pengembangan SDM. Tercapainya kemampuan SDM agar dapat memanfaatkan, mengembangkan dan menguasai IPTEK, maka ada beberapa hal yang dijadikan sebagai dasar, yaitu: a) Pembangunan IPTEK selayaknya berada dalam keseimbangan yang efektif juga dinamis dengan pembinaan SDM, pelaksanaan penelitian, pengembangan sarana prasarana IPTEK, b) Penyusunan IPTEK terarah pada peningkatan kehidupan bangsa dan kualitas kesejahteraan, c) Pembangunan IPTEK 
sepadan dengan nilai-nilai agama, kondisi sosial budaya, nilai luhur, dan lingkungan hidup, d) Penyusunan IPTEK harus berdasar pada upaya peningkatan efektivitas penelitian, efisiensi, produktivitas dan pengembangan yang lebih tinggi, e) Pembangunan IPTEK harus dapat memberikan solusi penyelesaian masalah konkret [16].

Proses penyempurnaan kurikulum atau pengembangan kurikulum menjadi otonomi sekolah. Sekolah diberi hak penuh dalam mengembangkan kurikulum, supaya kurikulum sekolah dicocokkan dengan kondisi sekolah masing-masing, yaitu menyesuaikan kondisi peserta didiknya dan potensi daerah yang ada [17]. Pendapat tersebut selaras dengan penyempurnaan yang terus dilakukan oleh pengembang kurikulum di Indonesia. Seringkali kita mendengar istilah "ganti menteri pendidikan, ganti kurikulum", padahal pergantian kurikulum sudah menjadi sesuatu yang biasa-biasa saja bagi negara di dunia dengan pendidikan yang maju. Hal itu dilakukan untuk mendorong relevansi pendidikan terhadap tantangan zaman, sehingga kurikulum yang diterapkan di lembaga pendidikan Indonesia tidak mungkin stagnan [18].

Pengembangan kurikulum bukan tentang abstraksi, akan tetapi mempersiapkan berbagai alternatif untuk tindakan yang merupakan inspirasi dari ide-ide dan beberapa penyesuaian lain yang dinilai penting [19]. Supaya kurikulum sesuai dengan perkembangan IPTEK maka harus memperhatikan kebutuhan masyarakat, industri, menyesuaikan dengan teknologi yang berkembang saat itu, menyesuaikan pola hidup, syarat dan tuntunan tenaga kerja, serta menginterpretasi kebutuhan individu dalam kerangka kepentingan IPTEK. Audrey Nicholls dan Howard Nicholls berpendapat bahwa pengembangan kurikulum ialah perencanaan kesempatan-kesempatan belajar agar membawa peserta didik ke arah perubahan-perubahan yang diinginkan dan mengukur sampai di mana perubahan tersebut telah terjadi dalam diri peserta didik [19].

Saat ini pemerintah dan seluruh penggerak pendidikan terus berjuang dan bekerja sama untuk mengembangkan kurikulum. Sebagaimana perkembangan saat ini, banyak inovasi pembelajaran yang diimplementasikan di berbagai sekolah, contohnya multimedia pembelajaran interaktif online, untuk media pembelajaran online baik audio, visual, maupun audio visual di antaranya: 1) Radio edukasi Kemdikbud, 2) suara edukasi, 3) Jogja belajar radio, 4) Podcast English first (podcast untuk belajar listening bahasa Inggris), 5) Sumber belajar Kemdikbud audio, 6) Google classroom, 7) Microsoft teams, 8) Moodle, 9) Kelas digital rumah belajar Kemdikbud, 10) Zoom, 11) Ruang guru, 12) Zenius, 13) Quipper, 14) Visual novel berbasis gamifikasi dan banyak lagi aplikasi serta media lainnya, kemudian evaluasi pembelajaran dengan menggunakan geschool.net yang dapat diakses melalui smartphone, iphone, ataupun komputer.

Selain itu, peranan pendidik sangat penting dalam penyampaian materi ajar yang telah disusun dalam kurikulum. Dengan demikian, pengembangan IPTEK dalam pengembangan kurikulum harus dilakukan oleh pendidik melalui pemanfaatan media belajar, sumber belajar, sistem penyampaian, pengembangan dimulai dengan unit-unit belajar yang melibatkan berbagai langkah disertai dengan uji coba diteruskan dengan unit-unit lain.

\section{SIMPULAN}

Berdasarkan analisis di atas, dapat disimpulkan sebagai berikut: Pertama, lembaga pendidikan, khususnya jalur 
sekolah harus mampu menunjang dan mengantisipasi perkembangan IPTEK baik yang dihadapi saat ini maupun tantangan masa depan. Kedua, materi atau bahan ajar sepatutnya hasil perkembangan IPTEK kontemporer, baik berkaitan dengan hasil perolehan informasi, ataupun cara memperoleh informasi tersebut dan memanfaatkannya untuk masyarakat. Ketiga, pengembang kurikulum memperhatikan kebutuhan masyarakat, industri, pola hidup, lapangan kerja, serta menginterpretasi kebutuhan individu dalam kerangka kepentingan IPTEK supaya kurikulum sesuai dengan perkembangan IPTEK. Keempat, dibutuhkan pemanfaatan, pengembangan dan penguasaan IPTEK yang akan memberi implikasi terhadap pengembangan sumber daya manusia.

\section{DAFTAR PUSTAKA}

[1] Kompas.com. "Indeks Modal Manusia Indonesia Kalah Jauh dari Singapura dan Vietnam". Jakarta, 2019.

[2] M. I. Dacholfany. "Inisiasi Strategi Manajemen Lembaga Pendidikan Islam dalam Meningkatkan Mutu Sumber Daya Manusia Islami di Indonesia dalam Menghadapi Era Globalisasi". At-Tajdid, vol. 1, no. 1, pp. 1-13, 2017.

[3] R. N. Sajidan. Peningkatan Proses Pembelajaran dan Penilaian Pembelajaran Abad 21 dalam Meningkatkan Kualitas Pembelajaran SMK. Surakarta: Direktorat Pembinaan SMK, 2018.

[4] Munir. Kurikulum Berbasis Teknologi Informasi dan Komunikasi. Bandung: Alfabeta, 2010.

[5] R. N. Siregar. "Konsep Dasar Pengembangan Kurikulum Pendidikan Agama Islam di Sekolah". Stud. Multidisipliner, vol. 4, no. 2, pp. 67-89, 2017.
[6] Alhamuddin. "Sejarah Kurikulum di Indonesia". Nur El-Islam, vol. 1, no. 2, pp. 48-58, 2014.

[7] Z. Arifin. Konsep dan Model Pengembangan Kurikulum. Bandung: Remaja Rosdakarya, 2017.

[8] R. Ariani. “Analisis Landasan Ilmu Pengetahuan dan Teknologi Pendidikan dalam Pengembangan Multimedia Interaktif Program Pasca Sarjana Pendidikan Fisika, FMIPA Universitas Negeri Padang". $J$. Penelit. Pembelajaran Fis., vol. 5, no. 2, pp. 155-162, 2019.

[9] N. S. Sukmadinata. Pengembangan Kurikulum. Teori dan Praktek. Bandung: Remaja Rosdakarya, 2017.

[10] Nazwirman. "Pembangunan IPTEK di Indonesia". Cakrawala, vol. 10, no. 1, pp. 43-49, 2010.

[11] Nurmadiah. "Kurikulum Pendidikan Agama Islam". J. AL-AFKAR, vol. III, no. Kurikulum, p. 43, 2014.

[12] T. Suharto. Filsafat Pendidikan Islam. Yogyakarta: AR-RUZZ MEDIA, 2013.

[13] D. Sukirman \& A. Nugraha. Landasan Pengembangan Kurikulum. 2014.

[14] M. Ibrahim. Pengembangan Kurikulum dan Pembelajaran Biologi. Tangerang Selatan: Universitas Terbuka, 2012.

[15] M. Putri. "Manajemen Kurikulum Program Basic Technology Education (Pendidikan Teknologi Dasar) di SMP AL Kautsar Bandar Lampung". Tesis. Universitas Lampung. Bandar Lampung, 2016.

[16] O. Hamalik. Kurikulum dan Pembelajaran. Jakarta: Bumi Aksara, 2013.

[17] S. Subarkah. "Manajemen Pengembangan Kurikulum SMP Alam Al Aqwiya Cilongok Banyumas". Tesis. IAIN Purwokerto, 2016.

[18] M. Asri. "Dinamika Kurikulum di 
Indonesia". Model. J. Progr. Stud. PGMI, vol. 4, no. 2, pp. 192-202, 2017.

[19] O. Hamalik. Manajemen Pengembangan Kurikulum. Bandung: Remaja Rosdakarya, 2010. 